Article

\title{
The Application of 40Ti-35Ni-25Nb Filler Foil in Brazing Commercially Pure Titanium
}

\author{
Shan-Bo Wang ${ }^{1}$, Chuan-Sheng Kao ${ }^{1}$, Leu-Wen Tsay ${ }^{2}$ (1) and Ren-Kae Shiue ${ }^{1, * \text { (i) }}$ \\ 1 Department of Materials Science and Engineering, National Taiwan University, Taipei 106, Taiwan; \\ j9280108@gmail.com (S.-B.W.); d03527005@ntu.edu.tw (C.-S.K.) \\ 2 Institute of Materials Engineering, National Taiwan Ocean University, Keelung 202, Taiwan; \\ b0186@mail.ntou.edu.tw \\ * Correspondence: rkshiue@ntu.edu.tw; Tel.: +886-2-33664533
}

Received: 7 February 2018; Accepted: 26 February 2018; Published: 1 March 2018

\begin{abstract}
The clad ternary 40Ti-35Ni-25Nb (wt \%) foil has been applied in brazing commercially pure titanium (CP-Ti). The wavelength dispersive spectroscope (WDS) was utilized for quantitative chemical analyses of various phases/structures, and electron back scattered diffraction (EBSD) was used for crystallographic analyses in the brazed joint. The microstructure of brazed joint relies on the $\mathrm{Nb}$ and $\mathrm{Ni}$ distributions across the joint. For the $\beta$-Ti alloyed with high $\mathrm{Nb}$ and low $\mathrm{Ni}$ contents, the brazed zone (BZ), consisting of the stabilized $\beta$-Ti at room temperature. In contrast, eutectoid decomposition of the $\beta$-Ti into $\mathrm{Ti}_{2} \mathrm{Ni}$ and $\alpha$-Ti is widely observed in the transition zone (TZ) of the joint. Although average shear strengths of joints brazed at different temperatures are approximately the same level, their standard deviations decreased with increasing the brazing temperature. The presence of inherent brittle $\mathrm{Ti}_{2} \mathrm{Ni}$ intermetallics results in higher standard deviation in shear test. Because the Ni content is lowered in $\mathrm{TZ}$ at a higher brazing temperature, the amount of eutectoid is decreased in TZ. The fracture location is changed from TZ into BZ mixed with $\alpha$ and $\beta$-Ti.
\end{abstract}

Keywords: vacuum brazing; titanium; eutectoid; clad filler foil; microstructure

\section{Introduction}

Titanium (Ti) and its alloys are characterized with high specific strength, good corrosion resistance, and excellent biocompatibility [1]. They are currently applied in aerospace, petroleum, and bio industries [2]. For instance, pure Ti has received great attention in medical applications. Improvement of its mechanical properties by selective laser melting has been performed in order to enhance the biomechanical compatibility of Ti implants [3]. High-strength and ductile $\beta$-Ti was successfully proposed for structural application [4]. Selective laser melting was applied to manufacture the fully dense $\mathrm{Ti} / \mathrm{TiB}$ composite for medical application [5]. The importance of $\mathrm{Ti}$ and its alloys are increasing in recent years.

Commercially pure titanium (CP-Ti) is unalloyed in purity from 99.0 to $99.5 \mathrm{in} \mathrm{wt} \mathrm{\%} \mathrm{[2,6].} \mathrm{There}$ are four grades of $\mathrm{CP}-\mathrm{Ti}$ according to the contents of impurities, such as iron and interstitial elements, hydrogen, carbon, nitrogen, and oxygen. Increasing the amount of impurities in CP-Ti results in increasing its strength, but its ductility is deteriorated [2,7]. Grade $2 \mathrm{CP}-\mathrm{Ti}$ is widely used due to its comprised strength and ductility.

Brazing of Ti and its alloys can be an important issue in application of such materials [8]. Most titanium alloys can be successfully brazed by Ti-(Zr)-Cu-Ni braze alloys [8-10]. Traditional Ti-based brazing fillers are alloyed with $\mathrm{Cu}$ and $\mathrm{Ni}$ as the melting point depressants, and they are featured with moderate brazing temperature and excellent bonding strength. However, the introduction of $\mathrm{Cu}$ into the braze alloy results in great concern, since the $\mathrm{Cu}$ is considered as a toxic ingredient for 
most bio applications [11]. The $\mathrm{Nb}$ metal is considered as a non-toxic element, and it shows good biocompatibility [12]. Although the $\mathrm{Nb}$ has a high melting point of $2469^{\circ} \mathrm{C}$, the melting temperature of Ti-based braze alloy is slightly increased for $\mathrm{Nb}$ addition below 15 at \% [13]. Therefore, the $\mathrm{Cu}$ in $\mathrm{Ti}-\mathrm{Cu}-\mathrm{Ni}$ braze alloy can be replaced by $\mathrm{Nb}$ in the Ti-Ni-Nb braze alloy for biomedical application. The clad $40 \mathrm{Ti}-35 \mathrm{Ni}-25 \mathrm{Nb}$ (wt \%) foil is a promising filler metal in brazing many titanium alloys. Based on the related binary alloy phase diagrams, the $\beta$-Ti is soluble with $\mathrm{Nb}$, and the $\mathrm{Ni}$ addition into the Ti-based braze alloy is served as a melting point depressant [13]. However, the Ni content in the braze alloy is prone to react with the Ti-based substrate, and forms brittle intermetallics to deteriorate the bonding strength of the brazed joint [14,15].

Traditional analysis tools, such as scanning/transmission electron microscope (SEM/TEM), electron probe microanalyzer (EPMA) and high-power X-ray diffractometer (XRD), are not satisfactory in analysis of a brazed joint involved with phase transformation. XRD structural analysis is not suitable for miniature phase and/or structure identification of the brazed joint. On the other hand, SEM/EPMA observations present quantitative chemical compositions of the specific phase(s), but lack structural data to identify them. For example, the transformation between $\alpha$ and $\beta$ phases in the titanium alloy could not be accurately identified from SEM/EPMA analyses. On the other hand, the width of a brazed joint is usually below $100 \mu \mathrm{m}$, so slicing different brazed zones in order to make TEM examination are quite difficult. The electron backscatter diffraction (EBSD) technique has made a great achievement in recent years. The combination of morphology, element mapping, and crystallographic data makes it possible to analyze such a brazed joint undergoing phase transformation [16,17]. The purpose of this research is to perform phase identifications of $40 \mathrm{Ti}-35 \mathrm{Ni}-25 \mathrm{Nb}$ brazed $\mathrm{CP}-\mathrm{Ti}$ joints using EPMA/WDS and SEM/EBSD. Microstructural evolution and shear strengths of vacuum brazed joints are also evaluated in this study.

\section{Materials and Experimental Procedures}

CP-Ti templates with the dimension of $15 \mathrm{~mm} \times 7 \mathrm{~mm} \times 4.2 \mathrm{~mm}$ were used in the experiment. Brazing surfaces were ground by $\mathrm{SiC}$ papers up to grit 800 and subsequently ultrasonically cleaned in ethanol solution prior to vacuum brazing. The clad $40 \mathrm{Ti}-35 \mathrm{Ni}-25 \mathrm{Nb}(\mathrm{wt} \%)$ foil was used as the brazing filler metal with a thickness of $50 \mu \mathrm{m}$. Vacuum brazing of CP-Ti substrate was performed with a heating rate of $0.33^{\circ} \mathrm{C} / \mathrm{s}$ under a vacuum of $5 \times 10^{-3} \mathrm{~Pa}$, and brazed at $1000,1100,1200^{\circ} \mathrm{C}$ for $600 \mathrm{~s}$, respectively. All of the vacuum brazed specimens were preheated at $900{ }^{\circ} \mathrm{C}$ for $1800 \mathrm{~s}$ in order to achieve temperature equilibrium of brazed joints.

The brazed joint was cut by a low-speed diamond saw and experienced a standard metallographic procedure before inspection. A JEOL 8600SX electron probe microanalyzer (EPMA, JEOL Ltd., Tokyo, Japan) equipped with the wavelength dispersive spectroscope (WDS) was utilized for quantitative chemical analyses of various phases/structures in the brazed joint. Its operation voltage was $15 \mathrm{kV}$, and the minimum spot size was $1 \mu \mathrm{m}$. An FEI Quanta 650 field emission scanning electron microscope (FESEM, FEI Corp., Hillsboro, OR, USA) equipped with the Oxford Nordlys Max 3 electron back scattered diffraction (EBSD) was used for crystallographic analyses in order to identify various phases/structures in the brazed joint. Its operation voltage was set at 20 or $25 \mathrm{kV}$. For the specimen that was prepared for EBSD analysis was ground by SiC paper, polished by colloidal silica, and finally modified by using a Fischione SEM Mill 1060 (E.A. Fischione Instruments, Inc., Export, PA, USA).

Bonding strengths of brazed joints were evaluated by shear tests, and tests were carried out on three specimens for each brazing condition. Symmetrical double lap joints, CP-Ti/40Ti-35Ni$25 \mathrm{Nb} / \mathrm{CP}-\mathrm{Ti}$, were applied in shear tests $[14,18]$. Figure 1 displayed the schematic diagram of shear test specimen, and the shear test specimen was enclosed in a graphite fixture [18]. Two bold black lines, 3.5-mm wide, in the middle of the graph indicated the brazing filler foil. Shear tests were conducted using a Shimadzu AG-10 universal testing machine (Shimadzu Corp., Kyoto, Japan) with a constant crosshead speed of $0.0167 \mathrm{~mm} / \mathrm{s}$. Cross-sections of joints after brazing were cut with a low-speed 
diamond saw. Failure analysis of the joint after shear test was examined by a JEOL JSM 6510 scanning electron microscope (SEM, JEOL Ltd., Tokyo, Japan), with the operation voltage of $15 \mathrm{kV}$.

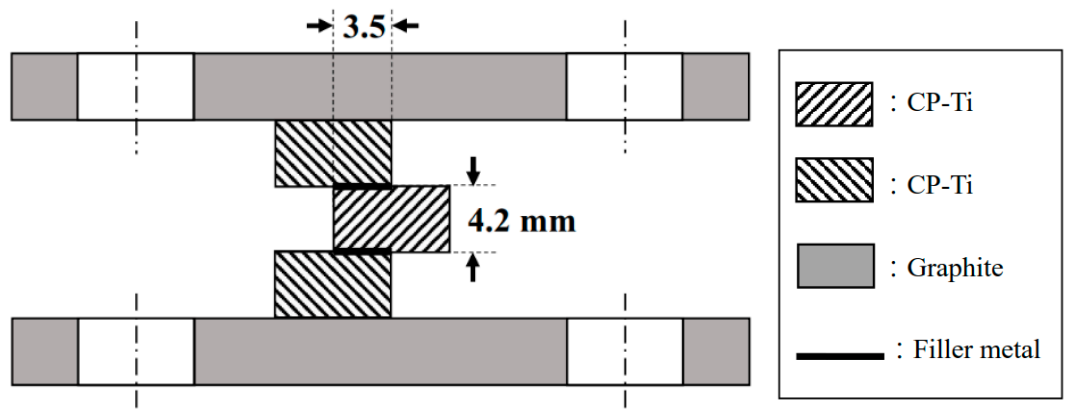

Figure 1. Schematic diagram of the shear test specimen [18].

\section{Results and Discussion}

Figure 2 displays the microstructural evolution of CP-Ti/Ti-35Ni-25Nb/CP-Ti joints at different brazing temperatures. Microstructures of central brazed zones (BZs) at 1000 and $1100{ }^{\circ} \mathrm{C}$ are similar. Increasing the brazing temperature causes an increase in the width of BZ. The microstructure of BZ at $1200{ }^{\circ} \mathrm{C}$ is different from those brazed at 1000 and $1100{ }^{\circ} \mathrm{C}$. BZ at $1200{ }^{\circ} \mathrm{C}$ contains two separated acicular phases. The microstructure of CP-Ti substrate is not included in Figure 2, and there is no acicular $\alpha$-Ti in CP-Ti substrate after brazing. At least two phases with acicular feature are observed in the transition zone (TZ) between the BZ and the CP-Ti substrate. One is white and the other is black in the backscattered electron images (BEIs) of Figure 2. The acicular shape of $\alpha$-Ti in the TZ is originated from the transformation of $\beta$-Ti upon cooling cycle of brazing. It is deduced that the white phase contains high atomic number element, such as $\mathrm{Nb}$, in BEIs, and will be discussed later.

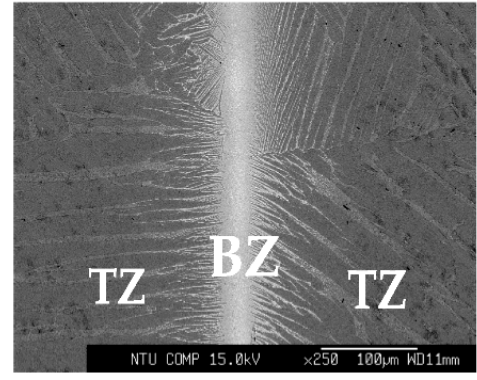

(a)

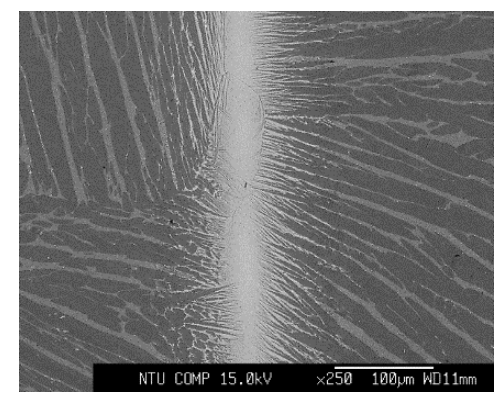

(b)

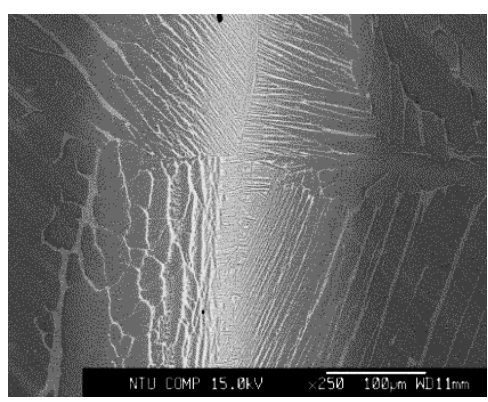

(c)

Figure 2. Electron probe microanalyzer (EPMA) backscattered electron images (BEIs) of CP-Ti/40Ti$35 \mathrm{Ni}-25 \mathrm{Nb} / \mathrm{CP}-\mathrm{Ti}$ joints brazed at (a) 1000 , (b) 1100 and (c), $1200{ }^{\circ} \mathrm{C}$ for $600 \mathrm{~s}$.

Figure 3 shows the EPMA BEIs of the joint brazed at $1000{ }^{\circ} \mathrm{C}$ for $600 \mathrm{~s}$, and WDS chemical analysis results are displayed in Table 1 . The brazed joint contains several distinct phases and structure. According to the EPMA chemical analysis, the white phase in the BZ is $\beta$-Ti, as marked by $\mathrm{A}$ in Figure $3 a$. The acicular white phase in TZ is identified as retained $\beta$-Ti as marked by $B$ in Figure $3 b$. Both $\mathrm{A}$ and $\mathrm{B}$ have similar chemical composition but different morphologies. The black acicular phase in TZ is $\alpha$-Ti alloyed with minor $\mathrm{Nb}$ and $\mathrm{Ni}$, as marked by $\mathrm{D}$ in the figure. It is noted that a eutectoid of $\mathrm{Ti}_{2} \mathrm{Ni}$ and $\alpha$-Ti is observed in the TZ next to $\mathrm{CP}$-Ti substrate, as marked by $\mathrm{E}$ in Figure $3 \mathrm{~b}$. Microstructures of TZ is changed from retained $\beta$-Ti plus acicular $\alpha$-Ti close to the BZ into eutectoid plus acicular $\alpha$-Ti next to CP-Ti substrate. 


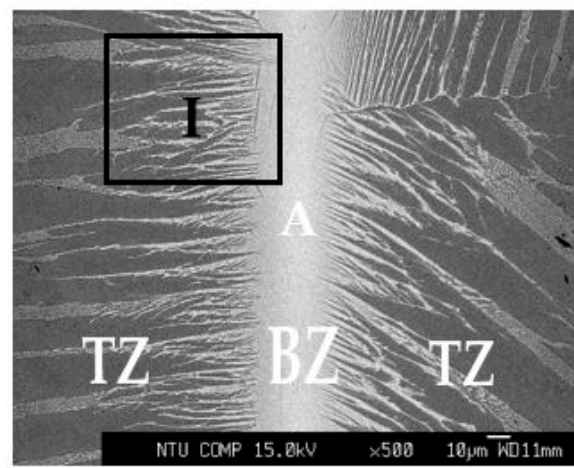

(a)

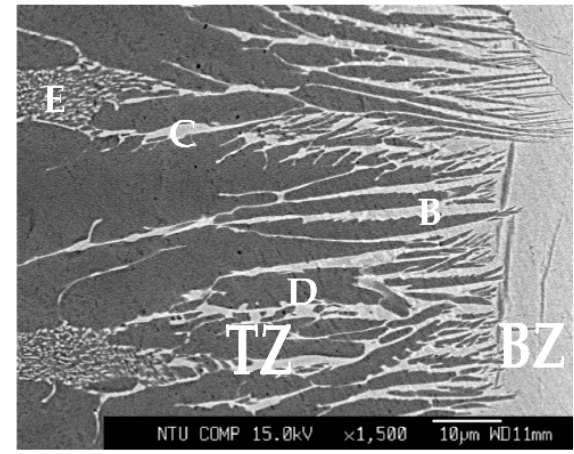

(b)

Figure 3. EPMA BEIs of CP-Ti/40Ti-35Ni-25Nb/CP-Ti joint brazed at $1000^{\circ} \mathrm{C}$ for $600 \mathrm{~s}:(\mathbf{a})$ cross section overview, (b) higher magnification of location I in (a).

Table 1. EPMA quantitative chemical analysis results in Figure 3.

\begin{tabular}{cccccc}
\hline at $\%$ & $\mathbf{A}$ & $\mathbf{B}$ & $\mathbf{C}$ & $\mathbf{D}$ & $\mathbf{E}$ \\
\hline $\mathrm{Nb}$ & 10.0 & 8.4 & 0.9 & 1.7 & 0.3 \\
$\mathrm{Ni}$ & 4.3 & 4.3 & 29.0 & 0.1 & 8.5 \\
$\mathrm{Ti}$ & 85.7 & 87.3 & 70.1 & 98.2 & 91.2 \\
Phase & $\beta-\mathrm{Ti}$ & retained $\beta-\mathrm{Ti}$ & $\mathrm{Ti}_{2} \mathrm{Ni}$ & $\alpha-\mathrm{Ti}$ & eutectoid \\
\hline
\end{tabular}

Figure 4 shows SEM/EBSD crystallographic analysis of the TZ between the BZ and CP-Ti substrate brazed at $1000{ }^{\circ} \mathrm{C}$ for $600 \mathrm{~s}$. According to Figure $4 \mathrm{~b}$, there are mixtures of retained $\beta$-Ti and $\mathrm{Ti}_{2} \mathrm{Ni}$ along lath boundaries of acicular $\alpha$-Ti. It is worth mentioning that retained $\beta$-Ti and $\mathrm{Ti}_{2} \mathrm{Ni}$ have similar color in BEIs (Figures $3 b$ and 4a). They can be easily distinguished by SEM/EBSD crystallographic analysis. According to Figure 4 , the TZ comprises of $\mathrm{Ti}_{2} \mathrm{Ni} / \alpha$-Ti eutectoid, retained $\beta$ - $\mathrm{Ti}$, and $\mathrm{Ti}_{2} \mathrm{Ni}$ along lath boundaries of acicular $\alpha$-Ti matrix. Because $\mathrm{Nb}$-Ni-Ti ternary alloy phase diagram in the Ti-rich corner is still not available, related binary alloy phase diagrams are cited in order to unveil microstructures of brazed joints $[13,19]$.

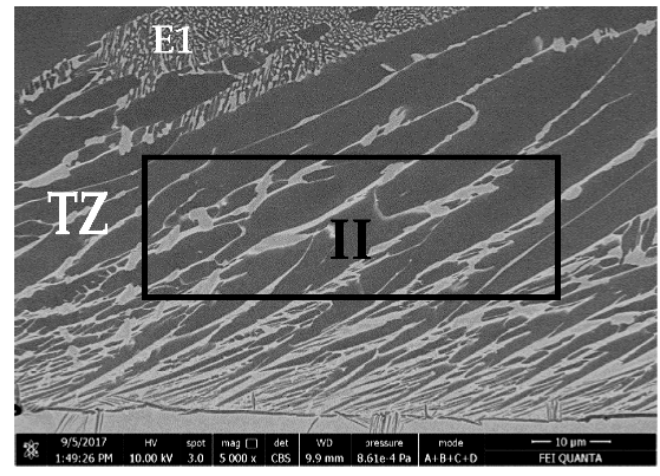

(a)

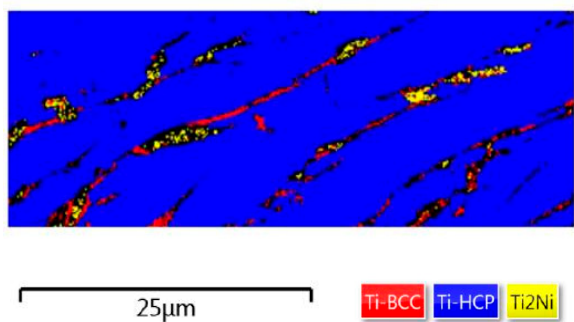

(b)

Figure 4. Scanning electron microscope (SEM)/electron back scattered diffraction (EBSD) analysis results of the transition zone (TZ) between the brazed zone (BZ) and CP-Ti substrate brazed at $1000^{\circ} \mathrm{C}$ for 600 s: (a) SEM/BEI, (b) EBSD map of location II in (a).

According to binary alloy phase diagrams of $\mathrm{Ti}-\mathrm{Nb}$ and $\mathrm{Ti}-\mathrm{Ni}$, the $\mathrm{Ni}$ could combine with $\mathrm{Ti}$ to form $\mathrm{Ti} 2 \mathrm{Ni}$, but it did not react with $\mathrm{Nb}$ in the experiment [13]. The $\alpha$-Ti dissolves $\mathrm{Nb}$ up to 2.5 at $\%$, and the $\mathrm{Nb}$ can be completely dissolved into $\beta$ - $\mathrm{Ti}$, i.e., $(\beta-\mathrm{Ti}, \mathrm{Nb})$. The chemical composition of 
$40 \mathrm{Ti}-35 \mathrm{Ni}-25 \mathrm{Nb}$ filler foil in at \% is $49.1 \mathrm{Ti}, 35.1 \mathrm{Ni}$, and $15.8 \mathrm{Nb}$. The melting point of Ti2 $\mathrm{Ni}$ is $984^{\circ} \mathrm{C}$, so it is formed upon cooling cycle of brazing if the brazing temperature exceeds $100{ }^{\circ} \mathrm{C}$. Increasing the brazing temperature enhances both dissolution of the CP-Ti substrate into the braze melt and diffusion of $\mathrm{Nb}$ and $\mathrm{Ni}$ from the braze melt into $\mathrm{CP}-\mathrm{Ti}$ substrate. The $\mathrm{Ni}$ is depleted from $\mathrm{BZ}$ and dissolved into the $\beta$-Ti up to 10 at \% during brazing [13]. Consequently, the coarse solidified Ti2Ni is absent from the joint brazed above $1000{ }^{\circ} \mathrm{C}$. The $\beta$-Ti is stabilized by alloying of $\mathrm{Nb}$. If the content of $\mathrm{Nb}$ is high enough to stabilize the $\beta$-Ti, retained $\beta$-Ti is obtained after brazing. In contrast, if the $\beta$-Ti alloyed with high $\mathrm{Ni}$ concentration does not consist of enough $\mathrm{Nb}$ content, then the $\beta$-Ti will decompose into fine eutectoid of $\alpha$-Ti and Ti2Ni, as demonstrated by label E in Figure 3b and E1 in Figure 4a. Phase diagrams show strong support with experimental observations.

Figure 5 displays EPMA BEIs of CP-Ti/40Ti-35Ni-25Nb/CP-Ti joint brazed at $1100{ }^{\circ} \mathrm{C}$ for $600 \mathrm{~s}$. EPMA quantitative chemical analysis results of Figure 5 are listed in Table 2 . In BZ, the $\beta$-Ti alloyed with $11.5 \mathrm{Nb}$ and $1.8 \mathrm{Ni}$ in at \% as marked by $\mathrm{F}$ in Figure $5 \mathrm{~b}$. High $\mathrm{Nb}$ concentration stabilizes the $\beta$-Ti to room temperature. The TZ close to BZ primarily comprises of retained $\beta$-Ti marked by G in Figure $5 b$. The acicular $\alpha$-Ti marked by $\mathrm{I}$ in Figure $5 \mathrm{~b}$ is alloyed with low $\mathrm{Nb}$ and $\mathrm{Ni}$ concentrations. In contrast, the retained $\beta$-Ti is stabilized by much higher $\mathrm{Nb}$ and $\mathrm{Ni}$ concentrations, as marked by $\mathrm{G}$ in Figure $5 \mathrm{~b}$.

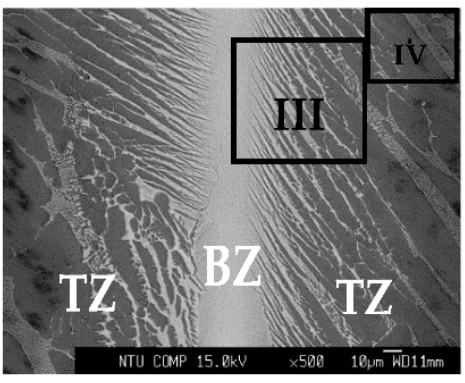

(a)

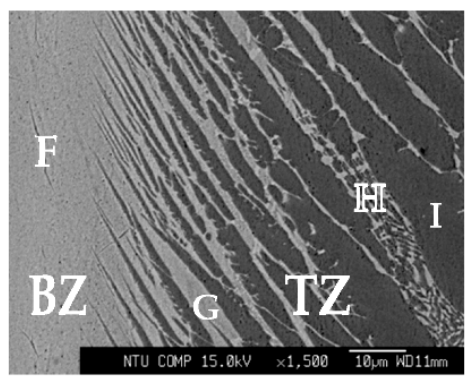

(b)

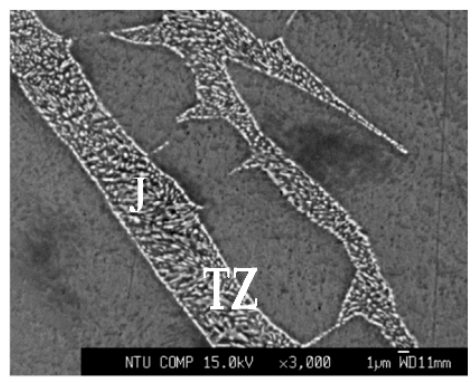

(c)

Figure 5. EPMA BEIs of CP-Ti/40Ti-35Ni-25Nb/CP-Ti joint brazed at $1100{ }^{\circ} \mathrm{C}$ for $600 \mathrm{~s}$ : (a) cross section overview, (b) higher magnification of location III in (a), (c) higher magnification of location IV in (a).

Table 2. EPMA quantitative chemical analysis results in Figure 6.

\begin{tabular}{cccccc}
\hline at $\%$ & $\mathbf{F}$ & $\mathbf{G}$ & $\mathbf{H}$ & $\mathbf{I}$ & $\mathbf{J}$ \\
\hline $\mathrm{Nb}$ & 11.5 & 8.3 & 0.2 & 1.2 & 0.1 \\
$\mathrm{Ni}$ & 1.8 & 5.4 & 15.0 & 0.1 & 9.3 \\
$\mathrm{Ti}$ & 86.7 & 86.3 & 84.8 & 98.7 & 90.6 \\
Phase & $\beta-\mathrm{Ti}$ & retained $\beta-\mathrm{Ti}$ & eutectoid & $\alpha-\mathrm{Ti}$ & eutectoid \\
\hline
\end{tabular}

Although both $\mathrm{Nb}$ and $\mathrm{Ni}$ can stabilize $\beta$-Ti, they take part in different roles [2]. $\mathrm{Nb}$-Ti belongs to $\beta$ isomorphous, and $\mathrm{Ni}-\mathrm{Ti}$ is classified as $\beta$ eutectoid. The transport mechanism of $\mathrm{Nb}$ and $\mathrm{Ni}$ from the BZ into CP-Ti substrate primarily relies on solid-state diffusion of $\mathrm{Nb}$ and $\mathrm{Ni}$ in $\beta$-Ti during brazing. The diffusion activation energies of $\mathrm{Nb}$ and $\mathrm{Ni}$ in $\beta$-Ti are 39.3 and $29.6 \mathrm{kcal} / \mathrm{mol}$, respectively [20]. Therefore, $\mathrm{Ni}$ has a much higher diffusivity in $\beta$-Ti than $\mathrm{Nb}$. According to the binary phase diagrams of $\mathrm{Nb}-\mathrm{Ti}$ and $\mathrm{Ni}-\mathrm{Ti}$, the $\beta$-Ti can be alloyed with $\mathrm{Ni}$ up to 10 at $\%$, but it cannot be stabilized to room temperature without alloying with $\mathrm{Nb}$ [13]. The $\mathrm{Ni}$ is alloyed in the retained $\beta$-Ti with 8.3 at $\% \mathrm{Nb}$, as illustrated at location $\mathrm{G}$ of Figure $5 \mathrm{~b}$. It is also noted that the eutectoid of $\mathrm{Ti}_{2} \mathrm{Ni}$ and $\alpha$-Ti is found in the TZ close to the CP-Ti substrate marked by $\mathrm{H}$ and $\mathrm{J}$ in Figure $5 \mathrm{~b}, \mathrm{c}$. The chemical compositions in at \% of location $\mathrm{J}$ are $90.6 \mathrm{Ti}$, 9.3 Ni, and $0.1 \mathrm{Nb}$. Slow diffusion of $\mathrm{Nb}$ in the $\beta$-Ti results in forming low $\mathrm{Nb}$ and high $\mathrm{Ni}$ contents of $\beta$-Ti, and it decomposes into fine eutectoid of $\mathrm{Ti}_{2} \mathrm{Ni}$ and $\alpha-\mathrm{Ti}$, as shown in Figure $5 \mathrm{c}$.

Figure 6 displays EPMA BEIs of CP-Ti/40Ti-35Ni-25Nb/CP-Ti joint brazed at $1200{ }^{\circ} \mathrm{C}$ for $600 \mathrm{~s}$. EPMA quantitative chemical analyses of Figure 6 are listed in Table 3. The microstructure of BZ at $1200{ }^{\circ} \mathrm{C}$ is quite different from those at 1000 and $1100^{\circ} \mathrm{C}$. The $\mathrm{BZ}$ is not a single phase anymore, and the 
$\beta$-Ti is decomposed into $\alpha$-Ti and retained $\beta$-Ti alloyed with 10.5 at $\% \mathrm{Nb}$ and 4.6 at $\% \mathrm{Ni}$ (marked by $\mathrm{K}$ ) in Figure $6 \mathrm{~b}$. High brazing temperature, e.g., $1200^{\circ} \mathrm{C}$, results in depletion diffusion of $\mathrm{Nb}$ from the $\mathrm{BZ}$ to TZ. Therefore, the $\beta$-Ti in BZ is decomposed into acicular $\alpha$-Ti and is retained $\beta$-Ti via eutectoid reaction. The microstructure of $\mathrm{TZ}$ contains retained $\beta$-Ti and eutectoid of $\mathrm{Ti}_{2} \mathrm{Ni}$ and $\alpha$-Ti along lath boundaries of acicular $\alpha$-Ti matrix. The chemical composition of eutectoid, as marked by $\mathrm{M}$ in Figure $6 \mathrm{c}$ is $91.3 \mathrm{Ti}, 0.3 \mathrm{Nb}$, and $8.4 \mathrm{Ni}$ in at \%. The $\beta$-Ti alloyed with high $\mathrm{Ni}$ and low $\mathrm{Nb}$ concentrations promotes eutectoid transformation into $\mathrm{Ti}_{2} \mathrm{Ni}$ and $\alpha$-Ti upon the cooling cycle of brazing.

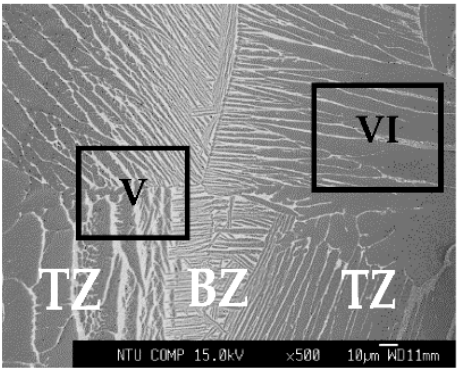

(a)

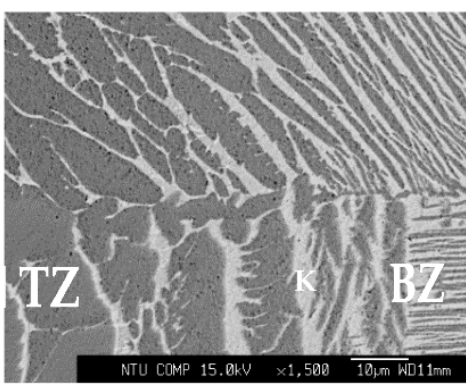

(b)

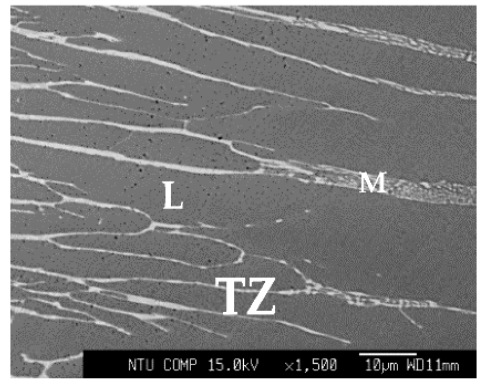

(c)

Figure 6. EPMA BEIs of CP-Ti/40Ti-35Ni-25Nb/CP-Ti joint brazed at $1200{ }^{\circ} \mathrm{C}$ for $600 \mathrm{~s}$ : (a) cross section overview, (b) higher magnification of location V in (a), (c) higher magnification of location VI in (a).

Table 3. EPMA quantitative chemical analysis results in Figure 6.

\begin{tabular}{cccc}
\hline at $\%$ & $\mathbf{K}$ & $\mathbf{L}$ & $\mathbf{M}$ \\
\hline $\mathrm{Nb}$ & 10.5 & 2.3 & 0.3 \\
$\mathrm{Ni}$ & 4.6 & 0.2 & 8.4 \\
$\mathrm{Ti}$ & 84.9 & 97.5 & 91.3 \\
Phase & retained $\beta-\mathrm{Ti}$ & $\alpha-\mathrm{Ti}$ & eutectoid \\
\hline
\end{tabular}

Figure 7 shows SEM/EBSD analysis results of the joint brazed at $1200{ }^{\circ} \mathrm{C}$ for $600 \mathrm{~s}$. According to Figure $7 \mathrm{a}, \mathrm{b}$, the BZ consists of acicular $\alpha$ and $\beta$-Ti. It is consistent with the EPMA analysis results (Figure 6 and Table 3). In the TZ, the eutectoid of $\mathrm{Ti}_{2} \mathrm{Ni}$ precipitates and $\alpha$-Ti is demonstrated in EBSD phase distribution map of location VIII in Figure 7c. It agrees with the EPMA chemical results of Figure $6 \mathrm{c}$ and Table 3. However, there are a few red retained $\beta$-Ti streaks in the eutectoid, as illustrated in Figure $7 \mathrm{~d}$. Streak-like $\mathrm{Ti}_{2} \mathrm{Ni}$ and retained $\beta$-Ti are identified along the lath boundaries of acicular $\alpha$-Ti matrix due to insufficient $\mathrm{Nb}$ alloyed in the $\beta$-Ti during brazing. Consequently, the stability of $\beta$-Ti is strongly related to its $\mathrm{Nb}$ content.

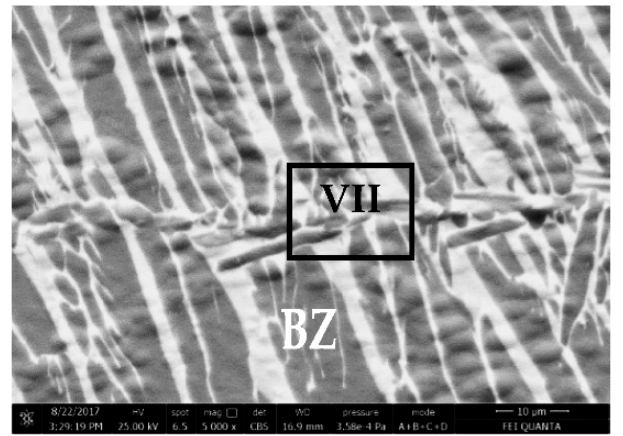

(a)

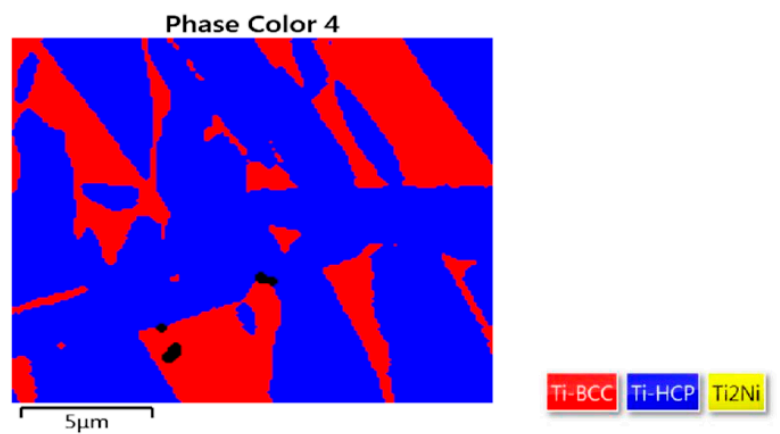

(b)

Figure 7. Cont. 


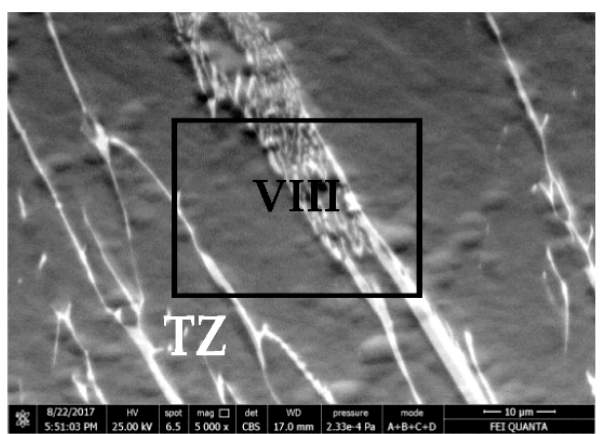

(c)

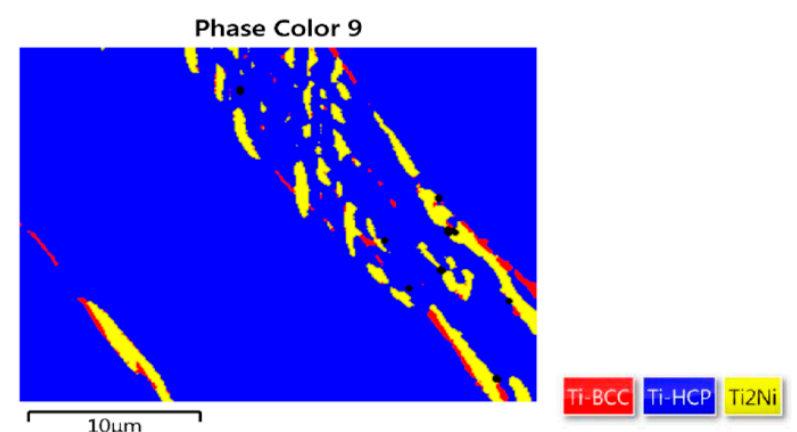

(d)

Figure 7. SEM/EBSD analysis results of the joint brazed at $1200^{\circ} \mathrm{C}$ for $600 \mathrm{~s}$ : (a) BEI of the BZ, (b) EBSD phase distribution map of location VII in (a), (c) BEI of the TZ, (d) EBSD phase distribution map of location VIII in (c).

Figure 8 displays the average shear strengths with standard deviations of CP-Ti/Ti-35Ni$25 \mathrm{Nb} / \mathrm{CP}-\mathrm{Ti}$ joints that are brazed at different temperatures. Both specimens brazed at 1000 and $1100{ }^{\circ} \mathrm{C}$ exhibit similar average shear strengths between 341 and $351 \mathrm{MPa}$. The average shear strength is slightly increased to $402 \mathrm{MPa}$ for the specimen brazed at $1200{ }^{\circ} \mathrm{C}$. In previous study, average shear strengths of dissimilar brazed high-strength Ti-6Al-4V and Ti-15-3 joints using Ti-Cu-Ni fillers are between 282 and $545 \mathrm{MPa}$, depending on the thermal history of brazing cycles [21]. The maximum average shear strength of brazed CP-Ti joint using $40 \mathrm{Ti}-35 \mathrm{Ni}-25 \mathrm{Nb}$ foil is $402 \mathrm{MPa}$ and it is acceptable in brazing $\mathrm{CP}-\mathrm{Ti}$.

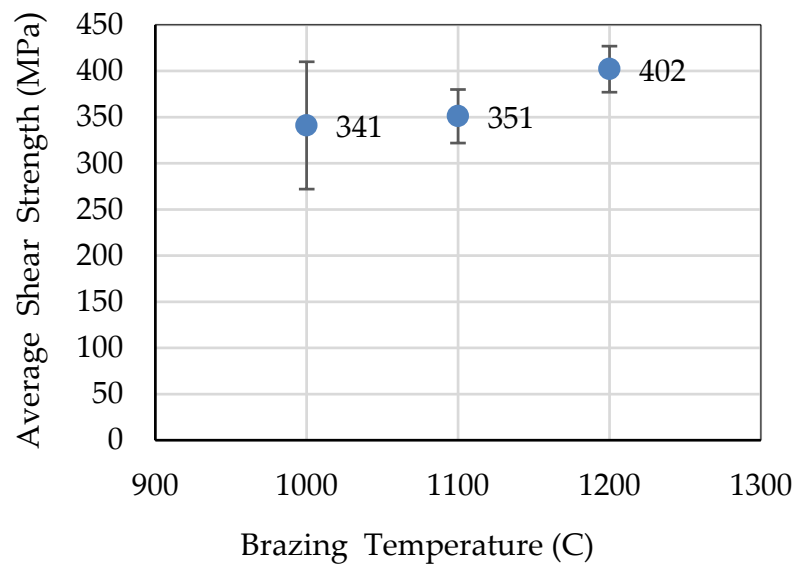

Figure 8. Average shear strengths of CP-Ti/40Ti-35Ni-25Nb/CP-Ti brazed joints.

Figure 9 shows BEI cross-sections and SEI fractographs of joints brazed at 1000,1100 , and $1200{ }^{\circ} \mathrm{C}$ for $600 \mathrm{~s}$, respectively. For specimens that were brazed at 1000 and $1100{ }^{\circ} \mathrm{C}$, cracks initiate from $\mathrm{Ti}_{2} \mathrm{Ni}$ and eutectoid of $\mathrm{TZ}$, and the cracking of acicular lath causes quasi-cleavage fracture being widely observed from SEI fractographs, as illustrated in Figure $9 a, b$. The fracture location changes from eutectoid and/or $\mathrm{Ti}_{2} \mathrm{Ni}$ in $\mathrm{TZ}$ to $\alpha / \beta$-Ti in $\mathrm{BZ}$ of the joint brazed at $1200{ }^{\circ} \mathrm{C}$. Higher brazing temperature enhances Ni depletion from BZ into CP-Ti substrate, so a wider joint is obtained. Volume fraction of $\mathrm{Ti}_{2} \mathrm{Ni}$ in $\mathrm{TZ}$ is decreased due to a lower Ni concentration in TZ. The SEI fractograph reveals isothermal solidified $\alpha / \beta-\mathrm{Ti}$ in BZ, as illustrated in Figure 9c. 

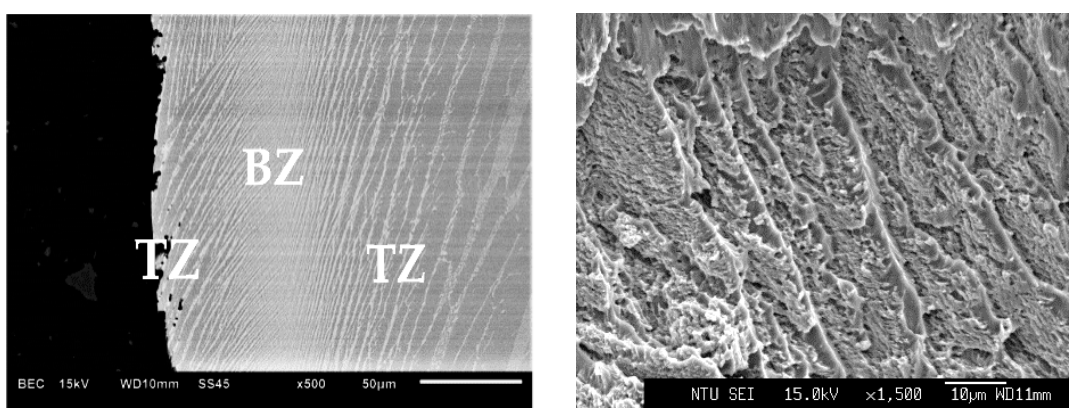

(a)
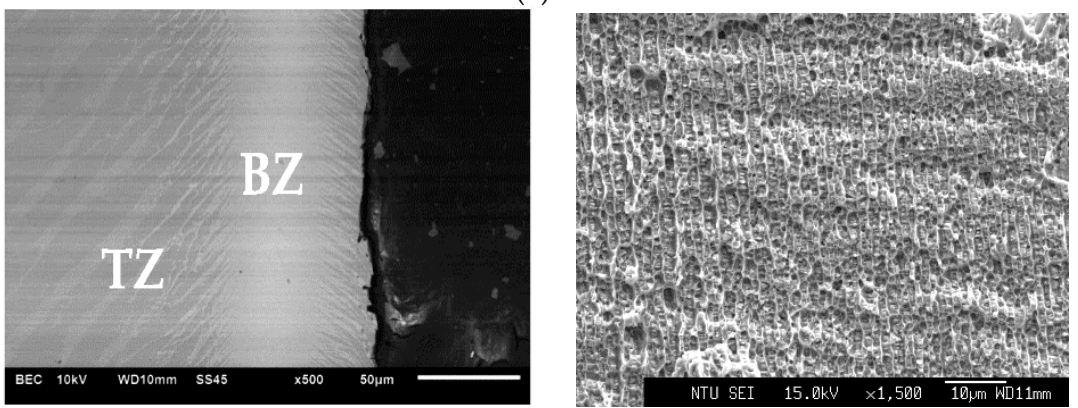

(b)
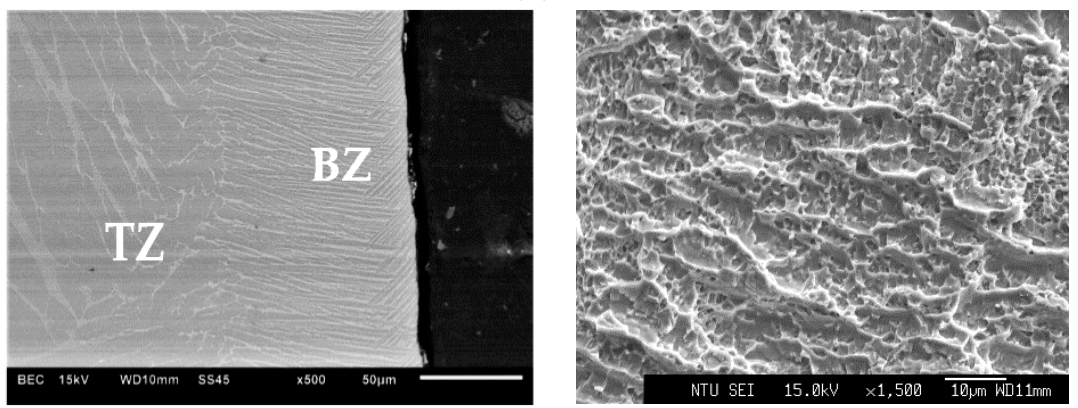

(c)

Figure 9. SEM BEI cross-sections and EPMA fractographs of joints brazed at (a) 1000, (b) 1100 and (c) $1200{ }^{\circ} \mathrm{C}$ for $600 \mathrm{~s}$.

Although the average shear strengths of joints brazed at different temperatures are approximately the same level, standard deviations of average shear strengths are quite different, as illustrated in Figure 8. The standard deviation of the joint brazed at $1000{ }^{\circ} \mathrm{C}$ demonstrates the highest value of $69 \mathrm{MPa}$. Increasing the brazing temperature to 1100 or $1200{ }^{\circ} \mathrm{C}$ results in decreasing the standard deviation to 29 or $25 \mathrm{MPa}$, respectively. The presence of inherent brittle $\mathrm{Ti}_{2} \mathrm{Ni}$ intermetallics results in higher standard deviation in the shear test result. It is preferred that a higher brazing temperature, such as $1200^{\circ} \mathrm{C}$, contributes to decrease the amount of $\mathrm{Ti}_{2} \mathrm{Ni}$ in the joint. The reliability of the brazed joint is improved in practical engineering application.

Heat treatment of the joint after brazing could be helpful to decrease the amount of brittle $\mathrm{Ti}_{2} \mathrm{Ni}$ in $\mathrm{TZ}$, and a tough joint could be obtained after brazing. However, the dissolution of $\mathrm{Ti}_{2} \mathrm{Ni}$ into $\beta$ - $\mathrm{Ti}$ is much more prominent than that into $\alpha$-Ti. The temperature of heat treatment must exceed $\beta$ transus temperature of the titanium alloy due to the high solubility of $\mathrm{Ni}$ in the $\beta$-Ti. It is worth mentioning that the $\beta$ transus temperature of the titanium alloy is strongly related to $\mathrm{Nb}$ and $\mathrm{Ni}$ concentrations in the Ti alloy. It had better be clarified before heat treating the brazed joint. Additionally, the $\beta$-Ti is completely soluble with $\mathrm{Nb}$, and dissolves $\mathrm{Ni}$ up to 10 at \% [13]. The application of $40 \mathrm{Ti}-35 \mathrm{Ni}-25 \mathrm{Nb}$ filler foil in brazing $\beta$-Ti alloy may obtain a joint free of the Ti-Ni intermetallic compound. It deserves to study in the future. 


\section{Conclusions}

Vacuum brazing of CP-Ti using the clad $40 \mathrm{Ti}-35 \mathrm{Ni}-25 \mathrm{Nb}$ (wt \%) filler foil was performed at 1000, 1100 , and $1200{ }^{\circ} \mathrm{C}$ for $600 \mathrm{~s}$. Microstructures of the brazed joints are strongly related to $\mathrm{Nb}$ and $\mathrm{Ni}$ depletion from the brazed joint into $\mathrm{CP}$-Ti substrate. Although both $\mathrm{Nb}$ and Ni stabilize $\beta$-Ti, they take part in different actions. The $\mathrm{Nb}$ belongs to $\beta$ isomorphous, and the $\mathrm{Ni}$ is categorized as $\beta$ eutectoid. The diffusion of $\mathrm{Ni}$ in $\beta$-Ti is much faster than that of $\mathrm{Nb}$ in $\beta$-Ti. The $\beta$-Ti is stabilized by alloying $\mathrm{Nb}$ over 10 at $\%$ in the $\mathrm{BZ}$ of joints brazed at 1000 and $1100{ }^{\circ} \mathrm{C}$. Increasing the brazing temperature to $1200{ }^{\circ} \mathrm{C}$ results in the depletion of the $\mathrm{Nb}$ from $\mathrm{BZ}$ into $\mathrm{CP}$-Ti substrate. The mixture of acicular $\alpha$ and $\beta$-Ti is identified in the BZ. In TZ of the brazed joint, retained $\beta$-Ti, eutectoid of $\mathrm{Ti}_{2} \mathrm{Ni} / \alpha-\mathrm{Ti}$ are formed along acicular $\alpha$-Ti lath boundaries. For the $\beta$-Ti alloyed with high $\mathrm{Ni}$ and low $\mathrm{Nb}$ contents, it decomposes into $\mathrm{Ti}_{2} \mathrm{Ni} / \alpha$-Ti eutectoid and/or lath boundary $\mathrm{Ti}_{2} \mathrm{Ni}$ intermetallics. Although the average shear strengths of joints brazed at different temperatures are approximately the same level, standard deviations of average shear strengths are quite different. The standard deviation of the joint brazed at $1000{ }^{\circ} \mathrm{C}$ demonstrates the highest value of $69 \mathrm{MPa}$. Increasing the brazing temperature to 1100 or $1200^{\circ} \mathrm{C}$ results in decreasing the standard deviation to 29 or $25 \mathrm{MPa}$, respectively. The presence of inherent brittle $\mathrm{Ti}_{2} \mathrm{Ni}$ intermetallics results in higher standard deviation in the shear test result. For joints brazed at 1000 and $1100{ }^{\circ} \mathrm{C}$, quasi-cleavage fracture in $\mathrm{TZ}$ is widely observed from the fractured surface. The fracture location is changed from eutectoid and $/$ or $\mathrm{Ti}_{2} \mathrm{Ni}$ in $\mathrm{TZ}$ into $\alpha / \beta-\mathrm{Ti}$ in $\mathrm{BZ}$ of the joint brazed at $1200{ }^{\circ} \mathrm{C}$. A higher brazing temperature enhances Ni depletion from $\mathrm{BZ}$ into CP-Ti substrate, so a wider joint is obtained. Volume fraction of $\mathrm{Ti}_{2} \mathrm{Ni}$ in $\mathrm{TZ}$ is decreased due to lower Ni concentration in TZ. The fractured surface consists of isothermal solidified $\alpha / \beta$-Ti in BZ. It is preferred that a higher brazing temperature, such as $1200{ }^{\circ} \mathrm{C}$, contributes to a decrease the amount of $\mathrm{Ti}_{2} \mathrm{Ni}$ in BZ and TR of the joint. The application of clad $40 \mathrm{Ti}-35 \mathrm{Ni}-25 \mathrm{Nb}$ filler foil demonstrates the potential in brazing CP-Ti for industrial use.

Acknowledgments: The authors gratefully acknowledge the financial support of this investigation by the Ministry of Science and Technology of Taiwan (Contract No. MOST 106-2221-E-002-174-MY3). Thanks to H.C.L. and C.Y.K. of Instrumentation Center, National Taiwan University for EPMA experiments.

Author Contributions: R.-K.S. and L.-W.T. designed the experiment and explained the data. S.-B.W. performed the experiment. C.-S.K. performed the EBSD analysis.

Conflicts of Interest: The authors declare no conflict of interest.

\section{References}

1. Davis, J.R. ASM Handbook Volume 2 Properties and Selection: Nonferrous Alloys and Special-Purpose Materials; ASM International: Cleveland, OH, USA, 1990; pp. 661-669.

2. Smith, W.F. Structure and Properties of Engineering Alloys; McGraw-Hill Book, Co.: New York, NY, USA, 1993; pp. $433-484$.

3. Attar, H.; Calin, M.; Zhang, L.C.; Scudino, S.; Eckert, J. Manufacture by selective laser melting and mechanical behavior of commercially pure titanium. Mater. Sci. Eng. A 2014, 593, 170-177. [CrossRef]

4. Attar, H.; Bonisch, M.; Calin, M.; Zhang, L.C.; Scudino, S.; Eckert, J. Selective laser melting of in situ titanium-titanium boride composites: Processing, microstructure and mechanical properties. Acta Mater. 2014, 76, 13-22. [CrossRef]

5. Okulov, I.V.; Wendrock, H.; Volegov, A.S.; Attar, H.; Kühn, U.; Skrotzki, W. High strength beta titanium alloys: New design approach. Mater. Sci. Eng. A 2015, 628, 297-302. [CrossRef]

6. Roger, R.; Collings, E.W.; Welsch, G. Materials Properties Handbook: Titanium Alloys; ASM International: Cleveland, OH, USA, 1993; pp. 1-3.

7. Walter, J.L.; Jackson, M.R.; Sims, C.T. Titanium and Its Alloys: Principles of Alloying Titanium; ASM International: Cleveland, OH, USA, 1988; pp. 23-33.

8. Yeh, T.Y.; Shiue, R.K.; Chang, C.S. Microstructural evolution of brazed CP-Ti using the clad Ti-20Zr-20Cu-20Ni foil. Metall. Mater. Trans. A 2013, 44, 9-14. [CrossRef] 
9. Yeh, T.Y.; Shiue, R.K.; Chang, C.S. Microstructural observation of brazed Ti-15-3 alloy using the clad Ti-20Zr-20Cu-20Ni foil. ISIJ Int. 2013, 53, 726-728. [CrossRef]

10. Humpston, G.; Jacobson, D.M. Principles of Soldering and Brazing; ASM International: Cleveland, OH, USA, 1993; pp. 31-69.

11. Okulov, I.V.; Volegov, A.S.; Attar, H.; Bonisch, M.; Ehtemam-Haghighi, S.; Calin, M. Composition optimization of low modulus and high-strength TiNb-based alloys for biomedical application. J. Mech. Behav. Biomed. Mater. 2017, 65, 866-871. [CrossRef] [PubMed]

12. Ehtemam-Haghighi, S.; Prashanth, K.G.; Attar, H.; Chaubey, A.K.; Cao, G.H.; Zhang, L.C. Evaluation of mechanical and wear properties of Ti-xNb-7Fe alloys designed for biomedical applications. Mater. Des. 2016, 111, 592-599. [CrossRef]

13. Massalski, T.B. Binary Alloy Phase Diagrams; ASM International: Cleveland, OH, USA, 1990.

14. Shiue, R.K.; Wu, S.K.; Chen, Y.T. Strong bonding of infrared brazed $\alpha_{2}-\mathrm{Ti}_{3} \mathrm{Al}$ and Ti-6Al-4V using Ti-Cu-Ni fillers. Intermetallics 2010, 18, 107-114. [CrossRef]

15. Zou, Z.H.; Zeng, F.H.; Wu, H.B.; Liu, J.; Li, Y.; Gu, Y.; Yuan, T.C.; Zhang, F.Q. The Joint strength and fracture mechanisms of TC4/TC4 and TA0/TA0 brazed with Ti-25Cu-15Ni braze alloy. J. Mater. Eng. Perform. 2017, 26, 2079-2085. [CrossRef]

16. Gey, N.; Humbert, M. Specific analysis of EBSD data to study the texture inheritance due to the $\beta \rightarrow \alpha$ phase transformation. J. Mater. Sci. 2003, 38, 1289-1294. [CrossRef]

17. Kurpaska, L.; Jozwik, I.; Jagieiski, J. Study of sub-oxide phases at metal-oxide interface in oxidized pure zirconium and Zr-1.0\% Nb alloy by using SEM/FIB/EBSD techniques. J. Nucl. Mater. 2016, 476, 56-62. [CrossRef]

18. Lin, C.Z.; Shiue, R.K. Vacuum brazing niobium using the clad 50Ti-35Ni-15Nb foil. Int. J. Refract. Met. Hard Mater. 2018, 71, 206-210. [CrossRef]

19. Villars, P.; Prince, A.; Okamoto, H. Handbook of Ternary Alloy Phase Diagrams Volume 10; ASM International: Cleveland, OH, USA, 1997; pp. 12805-12808.

20. Lide, D. CRC Handbook of Chemistry and Physics, 74th ed.; CRC Press: Ann Arbor, MI, USA, 1993; pp. $12-151$.

21. Chang, C.T.; Du, Y.C.; Shiue, R.K.; Chang, C.S. Infrared brazing of high-strength titanium alloys by Ti-15Cu-15Ni and Ti-15Cu-25Ni filler foils. Mater. Sci. Eng. A 2006, 420, 155-164. [CrossRef] 